\title{
A natural inhibitor of kidney-type glutaminase: a wesearch Paper from Physalis pubescens with potent anti-tumor activity
}

\author{
Canrong $\mathbf{W u}^{1}$, Mengzhu Zheng ${ }^{1}$, Suyu Gao², Shanshan Luan ${ }^{1}$, Li Cheng ${ }^{1}$, Liqing \\ Wang $^{2}$, Jiachen $\mathrm{Li}^{1}$, Lixia Chen ${ }^{2}$ and Hua $\mathrm{Li}^{1,2}$ \\ ${ }^{1}$ Hubei Key Laboratory of Natural Medicinal Chemistry and Resource Evaluation, School of Pharmacy, Tongji Medical College, \\ Huazhong University of Science and Technology, Wuhan 430030, P.R. China \\ ${ }^{2}$ Wuya College of Innovation, School of Traditional Chinese Materia Medica, Key Laboratory of Structure-Based Drug Design \\ and Discovery, Ministry of Education, Shenyang Pharmaceutical University, Shenyang 110016, P.R. China \\ Correspondence to: Hua Li, email: li_hua@hust.edu.cn \\ Lixia Chen, email: syzyclx@163.com
}

Keywords: KGA inhibitor; withanolide; physapubescin K; synergistic effects; structure-based virtual ligand screening

Received: July 12, $2017 \quad$ Accepted: November 14, $2017 \quad$ Published: December 08, 2017

Copyright: Wu et al. This is an open-access article distributed under the terms of the Creative Commons Attribution License 3.0 (CC BY 3.0), which permits unrestricted use, distribution, and reproduction in any medium, provided the original author and source are credited.

\section{ABSTRACT}

Kidney-type glutaminase (KGA), a mitochondrial enzyme converting glutamine to glutamate for energy supply, was over-expressed in many cancers and had been regarded as a promising therapeutic target in recent years. Structure-based virtual ligand screening predicted physapubescin $K$, a new withanolide from Physalis pubescens, to be potential KGA inhibitor. Enzyme activity inhibition assays and microscale thermophoresis experiments had demonstrated the efficiency and specificity of physapubescin K targeting KGA. Additionally, physapubescin K exhibited potent proliferation inhibitory effects on a panel of human cancer cell lines, such as SW1990 and HCC827-ER. It blocked glutamine metabolism in SW1990 with increasing intracellular level of glutamine and decreasing glutamate and its downstream metabolites. Physapubescin K also significantly inhibited the tumor growth in a SW1990 xenograft mouse model. Interestingly, physapubescin K could reverse the resistance of HCC827-ER cells to erlotinib and synergize with the hexokinase 2 inhibitor to markedly enhance the inhibition of SW1990 cell proliferation.

\section{INTRODUCTION}

Since Otto Warburg's pioneering work on aerobic glycolysis [1] was published, glucose has been a focus for cancer metabolic research. In recent years, researchers gradually found that other nutrients such as glutamine also played important roles in cancer metabolism [2-4]. Glutamine addiction, like Warburg effect, was also associated with dysregulation of metabolism pathways involved in cancers. As glucose was rapidly absorbed and converted to lactic acid, tumor cells were proposed to increase their use and uptake of glutamine, thereby producing alpha-ketoglutaric acid as the complementally fuel in Krebs cycle, as well as intermediates for the synthesis of lipids, nucleosides and other biomolecules required for cells' proliferation and survival $[5,6]$. Owing to the addiction of many cancer cells to glutamine, blocking glutamine metabolism was considered to be an attractive strategy for cancer therapy.

Gutaminases are mitochondrial enzymes that control the first step in the glutaminolysis pathway by converting glutamine to glutamate. Glutaminases possessed multiple tissue-specific forms, and was encoded by two genes in mammals. Kidney-type glutaminase (KGA) and glutaminase C (GAC) were encoded by GLS1 and livertype glutaminase (LGA) was encoded by GLS2 [7] GLS1 was broadly expressed in normal tissue and overexpressed in many cancer cells, thus played an important role in tumor metabolism [8]. Whereas GLS2 expression was restricted to the liver, brain, pancreas and pituitary gland. The dependence of cancer cells on glutamine metabolism made GLS1 an attractive anticancer target. It was reported that some oncogenes including c-Myc, Raf, Ras and Rho GTPase could up-regulate KGA expression 
in many cancer cells $[7,9,10,11,12]$. Treating tumor cells with KGA specific siRNA induced apoptosis under oxidative stress [13]. Therefore, KGA is proved to be an emerging target for cancer therapeutics [7, 12, 14, 15]. Although the potential benefits of KGA inhibition have been recognized for nearly 10 years, small molecule KGA inhibitors were relatively scarce, and merely few chemically synthesized derivatives, such as DON, BPTES and CB-839 were available until now [7, 14]. Among them, only CB-839 has moved on to clinic phase I trials $[6,16,17]$. Nevertheless, some shortcomings like nonspecificity, low solubility and moderate potency may limit its pharmacological applications.

Natural products have been acknowledged to be an important source for antitumor drug discovery and development [18]. Our group is making efforts to find small molecule KGA inhibitors with high potency and selectivity from natural products [19]. About 500 compounds from a small in-house database of natural products were screened against the KGA model in silico, as a result, a new withanolide with characteristic $\delta$-lactol side chain, physapubescin K from Physalis pubescens L., was discovered as a new natural KGA inhibitor, which showed potent anticancer activity both in vitro and in vivo and displayed synergistical inhibition of tumor cell growth with benserazide and erlotinib.

\section{RESULTS}

\section{Structure elucidation}

The molecular formula of physapubescin $\mathrm{K}$ was determined to be $\mathrm{C}_{31} \mathrm{H}_{44} \mathrm{O}_{8}$ via HRESIMS and NMR data. The NMR spectrosopic data (Table 1) suggested that physapubescin $\mathrm{K}$ possessed the typical withanolide skeleton, and it closely resembled physapubescin [20] except for an additional methoxyl signal $\left[\delta_{\mathrm{H}} 3.41(3 \mathrm{H}, \mathrm{s})\right.$, $\delta_{\mathrm{C}}$ 56.4]. In the HMBC spectrum, the signal at $\delta_{\mathrm{H}} 3.41$ correlated with $\delta_{\mathrm{C}} 101.4(\mathrm{C}-26)$, and $\delta_{\mathrm{H}} 4.50(\mathrm{H}-26)$ correlated with the methoxy carbon at $\delta_{\mathrm{C}} 56.4$, indicating that the methoxyl was attached to $\mathrm{C}-26$. The NOESY correlations between $\mathrm{H}-22$ and $\mathrm{H}-26 / \mathrm{H}-23_{\mathrm{eq}}$, between $\mathrm{CH}_{3}-27$ and $\mathrm{CH}_{3} \mathrm{O}-26$, and between $\mathrm{CH}_{3}-28$ and $\mathrm{H}-23_{\mathrm{ax}}$, suggested that the $\mathrm{CH}_{3} \mathrm{O}-26, \mathrm{CH}_{3}-27$, and $\mathrm{CH}_{3}-28$ were trans to $\mathrm{H}-22$. The $20 S, 22 R$-configuration of physapubescin $\mathrm{K}$ was determined through the characteristic coupling pattern of $\mathrm{H}-22: \delta_{\mathrm{H}} 3.47(1 \mathrm{H}, \mathrm{dt}, J$ $=11.5,2.9 \mathrm{~Hz}$ ) and NOESY correlations of $\mathrm{H}_{3}-21 / \mathrm{H}-23_{\mathrm{ax}}$, $\mathrm{H}-17 / \mathrm{H}-23$ eq, H-16 $\alpha / \mathrm{H}-22, \mathrm{H}-16 \beta / \mathrm{H}-22$, and H-22/H-20 $[21,22]$. Therefore, the structure of physapubescin $\mathrm{K}$ was assigned as shown in Figure 1.

\section{Virtual ligand screening}

To find new KGA inhibitors, 500 compounds from the in-house natural product library were screened against the KGA model in silico based on its X-ray structure (PDB code: 3VP1) [23]. Compounds with lower calculated binding energies were considered to have higher binding affinities with the target. The results predicted that physapubescin $\mathrm{K}$ exhibited the highest binding affinity to KGA with the most negative mfScores of -159.12 (Table 2). From the generated docking model, physapubescin $\mathrm{K}$ was adopted an extended conformation, which occupied the active site of the enzyme, hydrogen bonds were predicted between ketone group at C-1 and Lys320, as well as between hydroxyl at C-4 and carbonyl of Lys507. Also, physapubescin $\mathrm{K}$ formed key hydrophobic interactions between $\delta$-lactol ring and Tyr249, and between ring D and V484. The $\pi-\pi$ stacking interaction formed by ring B and Tyr466 further strengthens the binding (Figure 2).

\section{In vitro enzyme inhibition assay}

To validate the finding of the virtual ligand screening, the catalytic domain of human KGA (cKGA) was expressed by recombinant technique. The enzyme inhibition experiments demonstrated that physapubescin $\mathrm{K}$ could significantly inhibit the activity of KGA in vitro with $\mathrm{IC}_{50}$ value of $0.52 \pm 0.06 \mu \mathrm{M}$. This was even more potent than the known inhibitors CB-839 and BPTES with $\mathrm{IC}_{50}$ of $0.97 \pm 0.04 \mu \mathrm{M}$ and $8.37 \pm 0.24 \mu \mathrm{M}$, respectively (Figure 3A and Table 2). Enzyme kinetics has been measured to explore the mode of inhibition. As shown in Figure 3B and 3C, physapubescin $\mathrm{K}$ displayed a primarily non-competitive inhibition mechanism in low concentration characterized by dose-dependent decrease in Vmax and little effects on $\mathrm{Km}$ for glutamine, but showed competitive inhibition in higher concentration characterized by dose-dependent increases in $\mathrm{Km}$ for glutamine. As shown in Figure 3D, $5 \mu \mathrm{M}$ physapubescin $\mathrm{K}$ could completely inhibit the activity of KGA with the substrate concentration of $10 \mathrm{mM}$, however, the catalytic rate of cKGA was immediately increased from 0 to 0.02 $\Delta \mathrm{OD} / \mathrm{min}$ when the substrate concentration was increased from $10 \mathrm{mM}$ to $40 \mathrm{mM}$. This suggested that the inhibition caused by physapubescin $\mathrm{K}$ was reversible.

\section{Physapubescin K not only binding with recombinant cKGA but also with intracellular KGA}

To further investigate the interaction of the compound with KGA, microscale thermophoresis method (MST) was used to assay the binding affinity between physapubescin K and KGA. This technology can quantify protein-protein or protein-small molecule interactions with high sensitivity through detecting fluorescent changes of molecules during thermophoresis [24]. The equilibrium dissociation constant $(\mathrm{Kd})$ of physapubescin $\mathrm{K}$ was $3.03 \pm 0.38 \mu \mathrm{M}$ (Figure $4 \mathrm{~A}$ and Table 2), exhibiting strong binding affinity with cKGA under the buffer 
Table 1: ${ }^{1} \mathrm{H}$ NMR (600 MHz) and ${ }^{13} \mathrm{C}$ NMR (150 MHz) spectroscopic data of physapubescin $\mathrm{K}_{\text {in }} \mathrm{CDCl}_{3}, \delta$ in $\mathrm{ppm}$

\begin{tabular}{|c|c|c|}
\hline \multirow{2}{*}{ position } & \multicolumn{2}{|l|}{ Physapubescin $\mathrm{K}^{\mathrm{a}}$} \\
\hline & $\delta_{\mathrm{H},}(\mathrm{J}$ in $\mathbf{H z})$ & $\boldsymbol{\delta}_{\mathrm{C}}$ \\
\hline 1 & - & 202.1 \\
\hline 2 & $6.13, \mathrm{~d}(10.0)$ & 132 \\
\hline 3 & $6.89, \mathrm{dd}(10.0,5.9)$ & 142.3 \\
\hline 4 & $3.69, \mathrm{~d}(5.9)$ & 69.6 \\
\hline 5 & - & 63.5 \\
\hline 6 & 3.13, brs & 61.8 \\
\hline \multirow[t]{2}{*}{7} & $2.04, \mathrm{dd}(15.0,4.1)$ & 30.2 \\
\hline & $1.42, \mathrm{~m}$ & \\
\hline 8 & $1.64, \mathrm{~m}$ & 29 \\
\hline 9 & $0.97, \operatorname{td}(11.4,4.1)$ & 43.7 \\
\hline 10 & - & 47.5 \\
\hline \multirow[t]{2}{*}{11} & $1.76, \mathrm{~m}$ & 21.7 \\
\hline & $1.39, \mathrm{~m}$ & \\
\hline \multirow[t]{2}{*}{12} & $1.86, \mathrm{dt}(12.5,3.5)$ & 39.3 \\
\hline & $1.13, \mathrm{~m}$ & \\
\hline 13 & - & 42.9 \\
\hline 14 & $1.19, \mathrm{~m}$ & 58.7 \\
\hline 15 & $4.77, \operatorname{td}(9.4,2.7)$ & 76 \\
\hline \multirow[t]{2}{*}{16} & $2.03, \mathrm{~m}$ & 37.2 \\
\hline & $1.46, \mathrm{~m}$ & \\
\hline 17 & $1.23, \mathrm{~m}$ & 49.9 \\
\hline 18 & $0.68, \mathrm{~s}$ & 12.6 \\
\hline 19 & $1.34, \mathrm{~s}$ & 17.3 \\
\hline 20 & $1.61, \mathrm{~m}$ & 38.8 \\
\hline 21 & $0.83, \mathrm{~d}(6.5)$ & 12.7 \\
\hline 22 & $3.47, \mathrm{dt}(11.5,3.0)$ & 69.4 \\
\hline \multirow[t]{2}{*}{23} & $1.73, \mathrm{dd}(14.4,11.5)$ & 29.6 \\
\hline & $1.59, \mathrm{dd}(14.4,3.0)$ & \\
\hline 24 & - & 62.6 \\
\hline 25 & - & 61.3 \\
\hline 26 & $4.50, \mathrm{~s}$ & 101.4 \\
\hline 27 & $1.24, \mathrm{~s}$ & 14.6 \\
\hline 28 & $1.28, \mathrm{~s}$ & 19 \\
\hline \multirow[t]{2}{*}{$\mathrm{AcO}-15$} & $1.96, \mathrm{~s}$ & 170.7 \\
\hline & & 21.3 \\
\hline $\mathrm{OMe}$ & $3.41, \mathrm{~s}$ & 56.4 \\
\hline
\end{tabular}

condition. However, it was of vital importance to verify whether it could bind with the intracellular KGA. The cellular thermal shift assay (CETSA), which based on the biophysical principle of ligand-induced thermal stabilization of target protein [25], was thus conducted to investigate its affinity with intracellular KGA. The cellular thermal shift assay showed that physapubescin K was able to penetrate cells and stabilize KGA in intact SW1990 cells, indicating its strong affinity with the intracellular KGA. As shown in Figure 4B and 4C, physapubescin K increased the thermal stability of KGA in intact cells from tolerate temperature of $48^{\circ} \mathrm{C}$ to temperature of $50^{\circ} \mathrm{C}$. 


\section{Physapubescin K selectively inhibited the proliferation of glutamine-dependent cells SW1990 and HCC827-ER}

Effects of glutamine on the growth of four cells were analyzed, including pancreatic ductal carcinoma cell SW1990, erlotinib resistant non-small cell lung cancer cell HCC827-ER, breast cancer cell T47D, human normal liver cell LO2 (Figure 5A). As shown in Figure 5A, compared to that of T47D and LO2 cells, growths of SW1990 and HCC827-ER in glutamine-free media were markedly inhibited, indicating that both cells were glutaminedependent. In addition, SW1990 and HCC827-ER cells were sensitive to the treatment with $1 \mu \mathrm{M}$ physapubescin $\mathrm{K}$, but LO2 and T47D cells were not (Figure 5B). Glutamate can be used as the supplementary to compensate for the glutamate deprivation caused by the inhibition of KGA. In order to investigate whether the proliferation inhibitory effects of physapubescin $\mathrm{K}$ were mediated by inhibiting glutamine metabolism, glutamate supplementing assay was conducted. As shown in Figure 5C, addition of $2 \mu \mathrm{M}$ physapubescin $\mathrm{K}$ significantly inhibited cell proliferation while addition of $4 \mathrm{mM}$ glutamate did not affect cell proliferation, however, addition of $4 \mathrm{mM}$ glutamate remarkably alleviated the inhibition of cell growth induced by physapubescin K. Moreover, Western blot results showed the over-expression of KGA both in SW1990 and HCC27-ER cells (Figure 5D).

\section{Physapubescin K inhibited SW1990 cell proliferation both in vitro and in vivo}

EdU and DAPI double staining experiments showed that physapubescin K significantly inhibited the proliferation of SW1990 cells at the concentration of $5 \mu \mathrm{M}$, with the proliferated cell ratio close to zero, which was significantly better than the inhibitory effects of BPTES at
$40 \mu \mathrm{M}$ and CB-839 at $10 \mu \mathrm{M}$ (Figure 6A). The inhibitory effects of physapubescin $\mathrm{K}$ against human normal liver cell LO2, erlotinib-resistant human non-small cell lung cancer cells (HCC827-ER), human pancreatic cancer cells (SW1990), and human fibrosarcoma cells (HT1080) were further investigated using CCK8 method (Table 3). In addition, as shown in Figure 6B, the $\mathrm{IC}_{50}$ of this compound against SW1990 was $2.21 \pm 0.01 \mu \mathrm{M}$, more potential than known inhibitors $\mathrm{CB}-839$ and BPTES with $\mathrm{IC}_{50}$ of $13.06 \pm$ $0.57 \mu \mathrm{M}$ and $35.33 \pm 0.67 \mu \mathrm{M}$, respectively. What's more, physapubescin K could significantly increase intracellular reactive oxygen species (ROS) levels and induce apoptosis in SW1990 cells (Figure 6C and 6D).

In vivo $\mathrm{SW} 1990$ xenograft mouse model showed that intraperitoneal injection of $5 \mathrm{mg} / \mathrm{kg}$ physapubescin $\mathrm{K}$ could significantly inhibit the growth of the tumor $(P<0.01)$ and showed dose-dependent inhibition (Figure $6 \mathrm{E}$ and $6 \mathrm{~F})$.

\section{Physapubescin K could block glutamine metabolism}

Blocking glutamine metabolism can inhibit the growth and proliferation of glutamine-dependent cells, mainly because of blocking the production and utilization of glutamine metabolites. The effects of different concentrations of physapubescin $\mathrm{K}$ on the intracellular glutamine and its downstream metabolites were examined. The results showed that it could significantly reduce the consumption of glutamine in the SW1990 cells and decrease the production of glutamic acid and its downstream metabolites including oxaloacetic acid, aspartic acid, and malic acid (Figure 7A). Likewise, physapubescin $\mathrm{K}$ significantly reduced the proportion of NADPH/NADP ${ }^{+}$in SW1990 cells. Whereas, physapubescin $\mathrm{K}$ showed moderate effects on glutamine metabolism in T47D cells. These results indicated that physapubescin $\mathrm{K}$ blocked glutamine metabolism, thereby

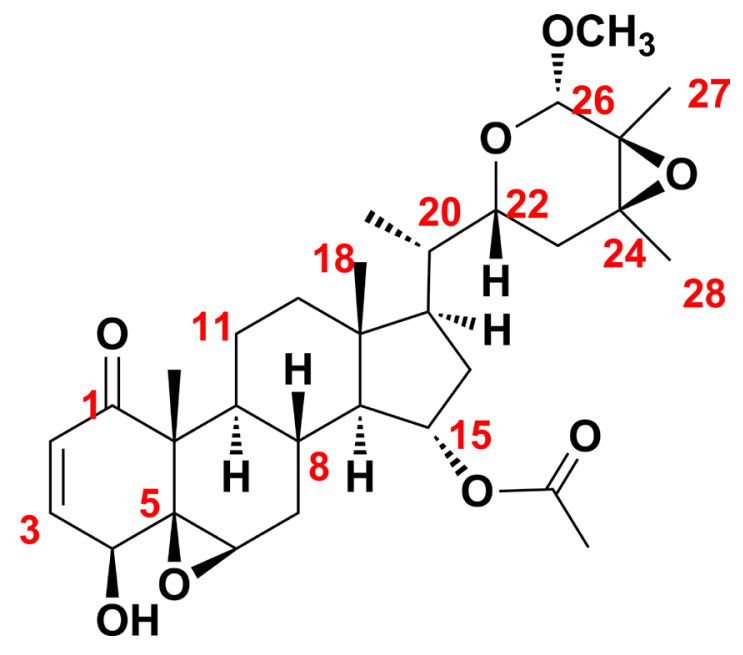

Figure 1: Chemical structure of physapubescin K. 
Table 2: Binding affinity and inhibitory activity of physapubescin K (PSBK) against KGA enzyme in vitro

\begin{tabular}{|c|c|c|c|}
\hline \multirow{2}{*}{ No. ${ }^{a}$} & \multirow{2}{*}{$\mathrm{mfScores}(\mathrm{kcal} / \mathrm{mol})^{\mathrm{b}}$} & \multicolumn{2}{|c|}{ KGA } \\
\hline & & $K d(\mu M)^{c}$ & $\mathrm{IC}_{50}(\mu \mathrm{M})$ \\
\hline PSBK & -159.12 & $3.03 \pm 0.38$ & $0.52 \pm 0.06$ \\
\hline CB-839 & N/A & $0.81 \pm 0.11$ & $0.97 \pm 0.04$ \\
\hline BPTES & $\mathrm{N} / \mathrm{A}$ & u.p & $8.37 \pm 0.24$ \\
\hline
\end{tabular}

${ }^{\mathrm{a}} \mathrm{CB}-839$ and BPTES were used as positive control.

${ }^{b} \mathrm{~N} / \mathrm{A}$ represents not available

'n.b. is no clear binding detected; u.p. represents un-performable in the MST measurement due to poor solubility of the compound.

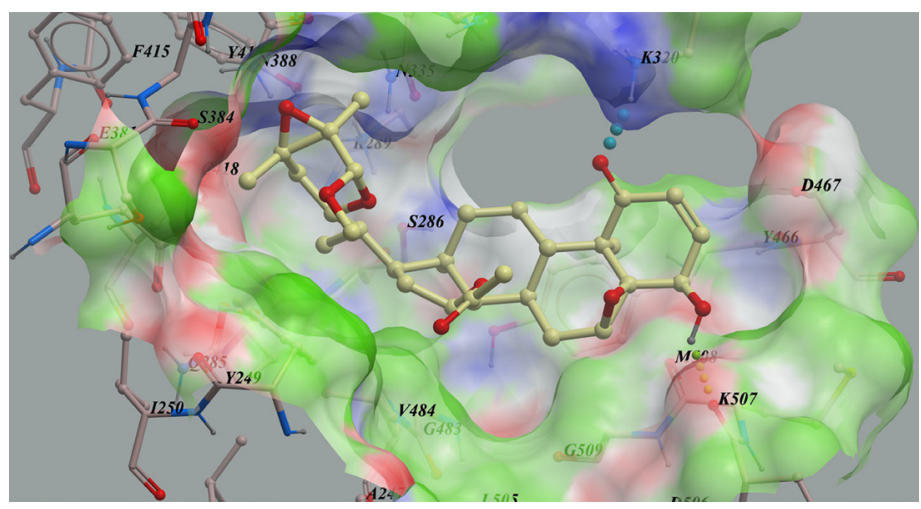

Figure 2: The low-energy binding conformations of physapubescin K bound to KGA generated by virtual ligand docking.

A

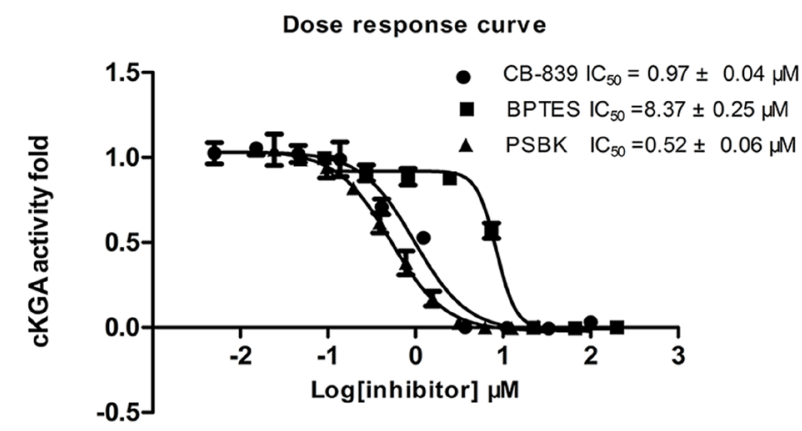

C

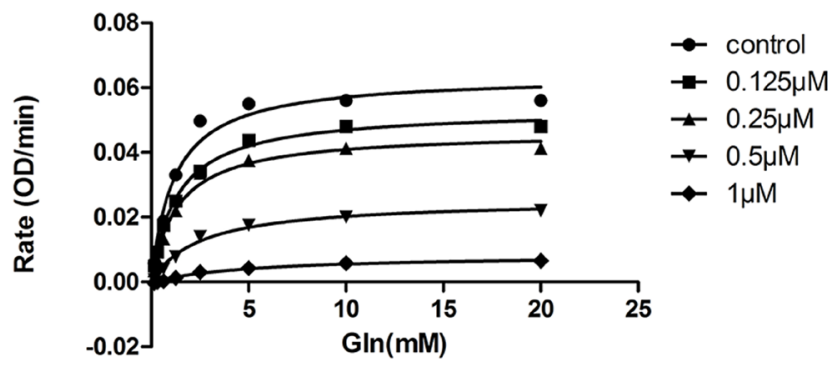

B

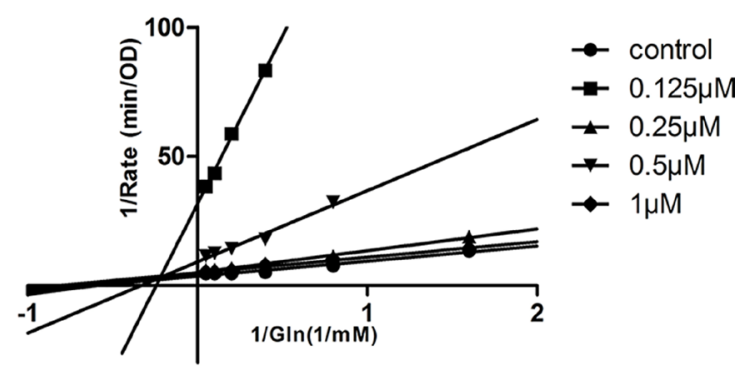

$\mathrm{D}$

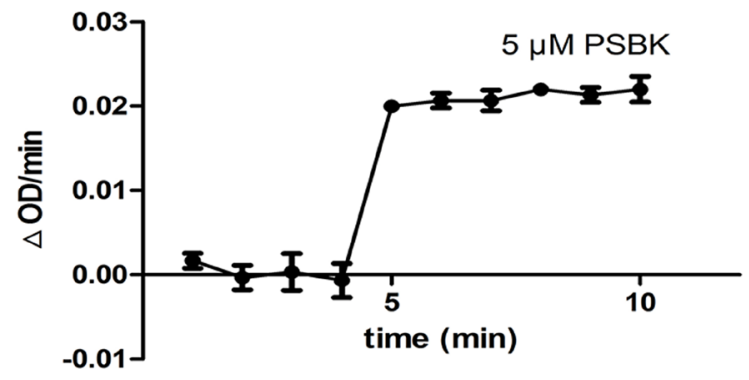

Figure 3: In vitro enzyme inhibition assay. (A) Dose response inhibition of cKGA activity by physapubescin K (PSBK), BPTES and CB-839 were used as positive control. (B) Line weaver-Burk double-reciprocal representation of the glutamine saturation profiles for KGA at a range of concentrations of physapubescin K. (C) Glutamine saturation profiles for KGA at a range of concentrations of physapubescin K. (D) Saturated inhibition assay. The glutamine was $10 \mathrm{mM}$ at $1-4 \mathrm{~min}$ and increased to $40 \mathrm{mM}$ at 4 min. Physapubescin $\mathrm{K}$ was $5 \mu \mathrm{M}$. 
reducing downstream products of the tricarboxylic acid cycle involved in providing energy and participating in the synthesis of bio-macromolecules, consequently inhibiting cell growth and proliferation. As shown in Figure 7B, relative cell vitalities of SW1990 treated with PSBK for 12 h, 24 h, $36 \mathrm{~h}$ and $48 \mathrm{~h}$ groups were $82.6 .3 \%, 50.3 \%, 37.6 \%, 27.3 \%$, respectively $\left({ }^{*} P<0.05 ;{ }^{* *} P<0.01 ;{ }^{* * *} P<0.001\right)$, indicating that the anti-proliferation effect of physapubescin $\mathrm{K}$ was in a time dependent manner. And the same effect could also be seen in Hcc827-ER cells (Figure 7C).

\section{Synergy of physapubescin $\mathrm{K}$ in combination treatments}

Tumor cells are speculated to maintain growth and proliferation through a variety of energy metabolism pathways. Therefore, targeting at a single energy metabolism material might not be an effective method for cancer therapy. It has been determined that growing cancer cells were strongly dependent on energy sources such as glucose and glutamine [26]. We supposed that the blocking of both glucose and glutamine metabolism pathways could display a synergistic tumor inhibition. Hexokinase 2 (HK2) was the crucial enzyme controlling the first step of glycolysis, and systemic deletion of HK2 can impair the tumor progression in mouse models. Nowadays, Metformin (Met), 2-Deoxyglucose (2-DG) and 3-Bromopyruvate (3-BrPA) are most commonly reported HK2 inhibitors. Because of the poor potency and side-effects of these compounds, developing novel potent HK2 inhibitors is a matter of great urgency. Benserazide was unexpectedly characterized as an HK2 inhibitor in our previous study [27]. The combined inhibitory effects of physapubescin $\mathrm{K}$ and benserazide on the growth of SW1990 cells were evaluated. As shown in Figure 8A, their combination could significantly enhance growth inhibitory activities against SW1990 cells. Figure 8B showed that combined use of physapubescin $\mathrm{K}$ and benserazide with ratio less than 1:50 to produce synergistic effects with a CI value less than 0.8 . The synergistic mechanism needs to be further investigated and the synergistic effect should be verified by in vivo models in future studies.

The epidermal growth factor receptor (EGFR) tyrosine kinase inhibitor (TKI) erlotinib has been used to treat non-small cell lung cancer (NSCLC) in clinic for a decade. However, cancer cells become resistant to the drug through various mechanisms. It was reported that erlotinib has an inhibitory activity against non-small cell lung cancer cell line $\mathrm{HCC} 827$ with $\mathrm{IC}_{50}$ of $1 \mathrm{nM}$. Whereas HCC 827-ER cell line could tolerate micromole level of erlotinib [28-30]. Previous study found that combination of GLS1 inhibitors and erlotinib markedly reduced EGFR expression despite weak to no effects of erlotinib or GLS1
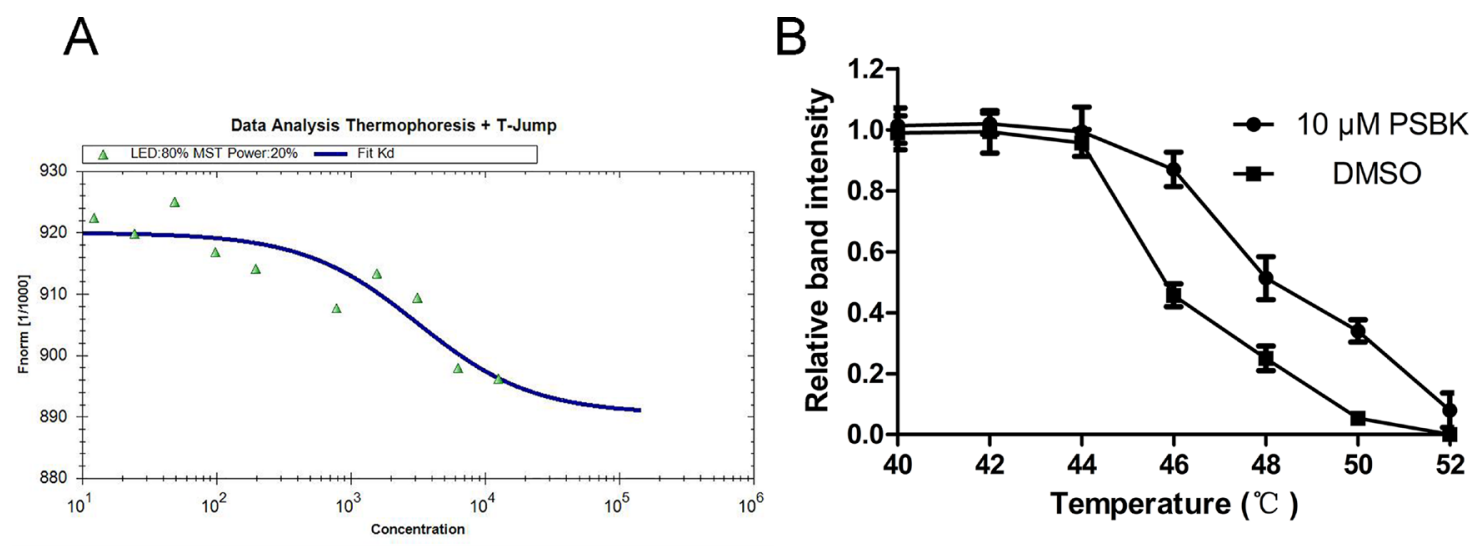

C

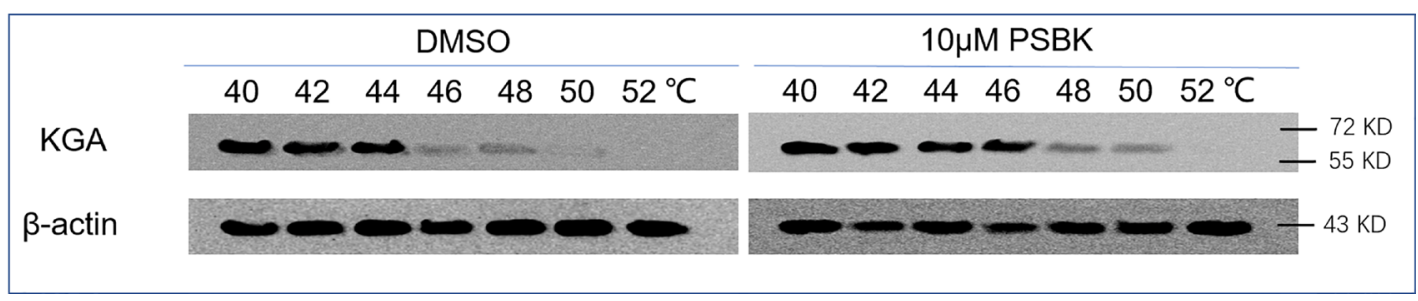

Figure 4: Physapubescin K (PSBK) not only binding with recombinant cKGA but also with intracellular KGA. (A) Measurement of affinity physapubescin K with KGA by MST in standard treated capillaries, and the resulting binding curve was shown $(\mathrm{Kd} 3.03 \pm 0.38 \mu \mathrm{M})$. (B-C) CETSA was performed on SW1990 cells as described in the Materials and Methods section. The stabilizing effects of physapubescin K on KGA and $\beta$-actin at different temperatures were evaluated by Western blot analysis (C). The intensity of the KGA bands was quantified using the Quantity One software (B). 
inhibitor alone on EGFR expression. Thus, blocking glutamine metabolism could improve the sensitivity of HCC827-ER to erlotinib [28].

In this study, the inhibitory effects of different concentrations of erlotinib (1, 2, 4, $8 \mu \mathrm{M})$ with physapubescin $\mathrm{K}(0.5 \mu \mathrm{M})$ on cell proliferation were compared with physapubescin $\mathrm{K}$ alone and erlotinib alone by double staining of EdU and DAPI. The results showed that physapubescin $\mathrm{K}$ could significantly increase the sensitivity of HCC827-ER to erlotinib (Figure 8D and 8E). The dose-dependent inhibition curve of physapubescin $\mathrm{K}$ on HCC827-ER was shown in Figure 8C.

\section{DISCUSSION}

It was reported that the growth of cancer cells was strongly dependent on energy sources such as glucose and glutamine [31]. Kidney-type glutaminase (KGA), a mitochondrial enzyme, was over expressed in many cancers, which has been determined as a promising target for cancer therapy in recent years [6]. To date, intense efforts have been made to develop the specific KGA inhibitors, which resulted in synthesis of DON, BPTES and CB-839 [7, 14]. Since de novo designing new targeted antitumor drug was not an easy task, natural products and their derivatives were another alternative way to obtain active lead compounds. Structure-based virtual ligand screening facilitated discovery of small-molecule KGA inhibitors in early stage. As our ongoing studies on natural KGA inhibitors [19], a new withanolide-type inhibitor physapubescin $\mathrm{K}$ was found from a small inhouse database of natural products through the above method. In vitro enzyme inhibition assay displayed that physapubescin $\mathrm{K}$ inhibited KGA in nanomole level
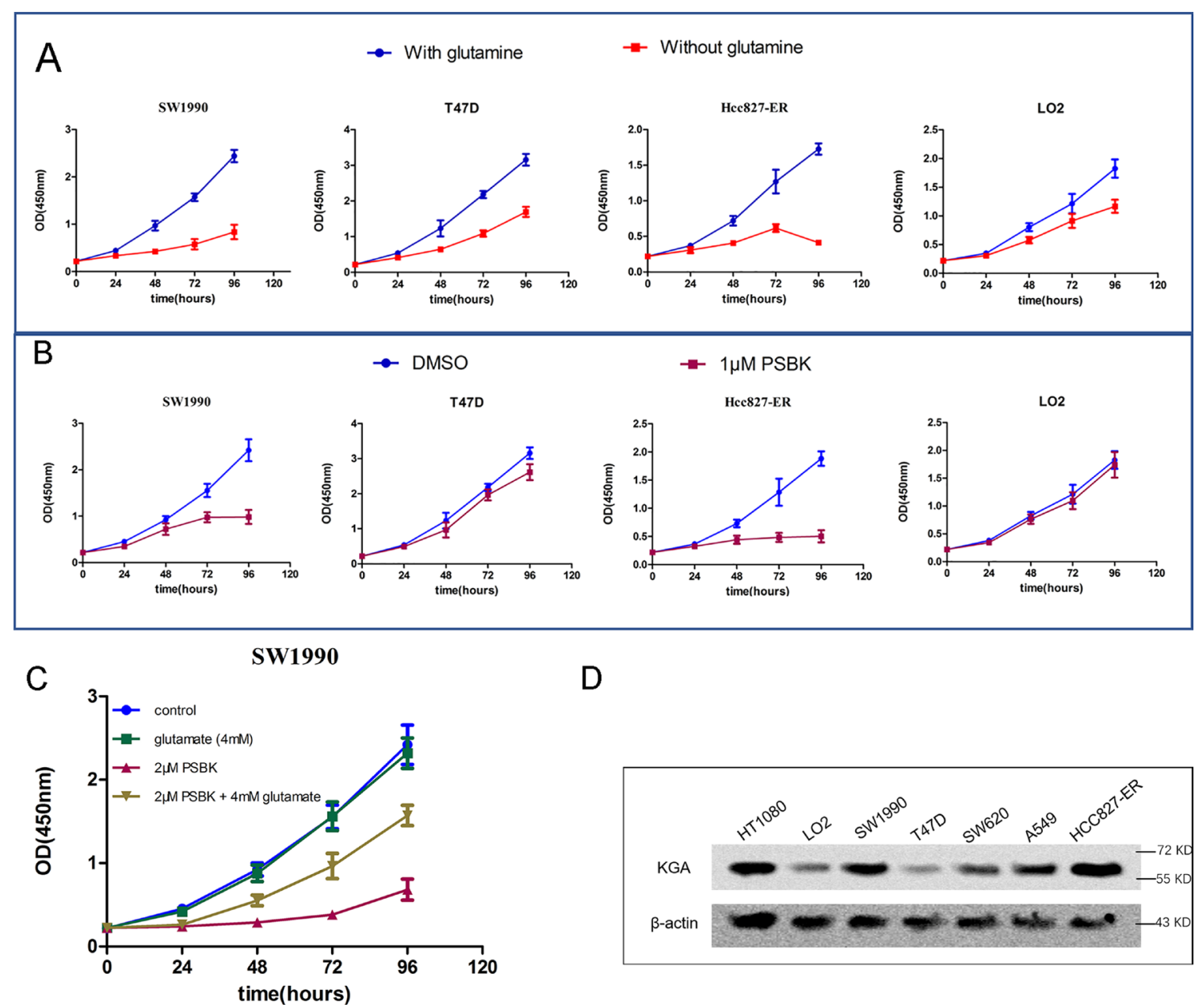

$\mathrm{D}$

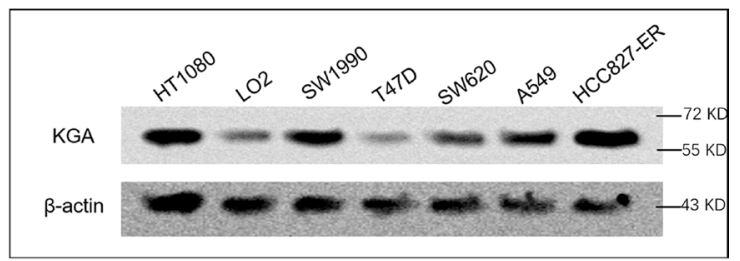

Figure 5: Physapubescin K selectively inhibit the proliferation of glutamine-dependent cells SW1990 and HCC827ER. (A) Effect of glutamine deprivation on the proliferation of cancer cells was incubated in DMEM containing $25 \mathrm{mM}$ glucose and $10 \%$ FBS, with or without $4 \mathrm{mM}$ glutamine. Data are shown as mean $\pm \mathrm{SD}(n=3$ per time point). (B) Cells treated with $1 \mu \mathrm{M}$ PSBK in $0.03 \%$ DMSO or with $0.03 \%$ DMSO (control). Data are shown as mean \pm SD ( $n=3$ per time point). (C) SW1990 cells were seeded at 20000 cells/mL with or without PSBK $(2 \mu \mathrm{M})$ and glutamate $(4 \mathrm{mM})$; viable cells were measured by CCK 8 on $24,48,36$ and $48 \mathrm{~h}$, respectively. (D) KGA expression levels in various cancer cells. 
A

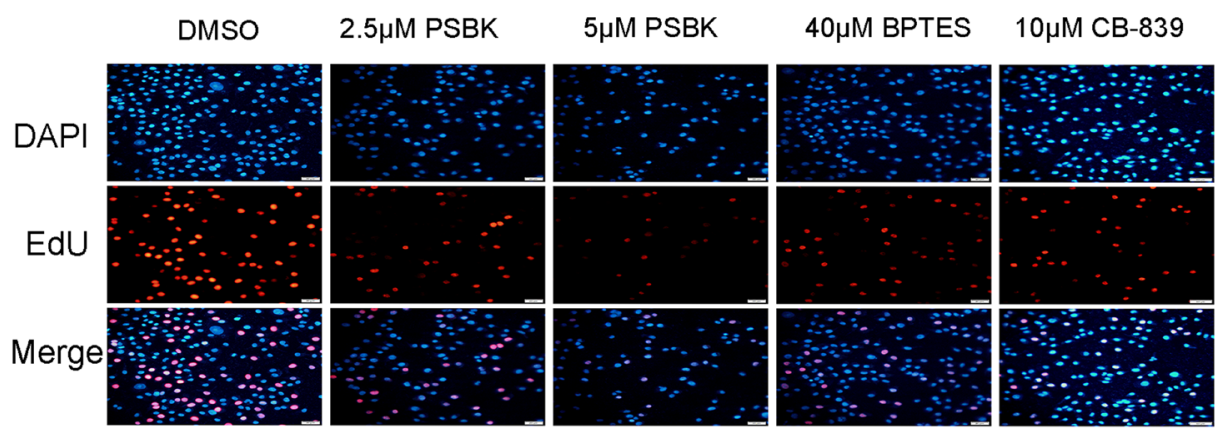

B
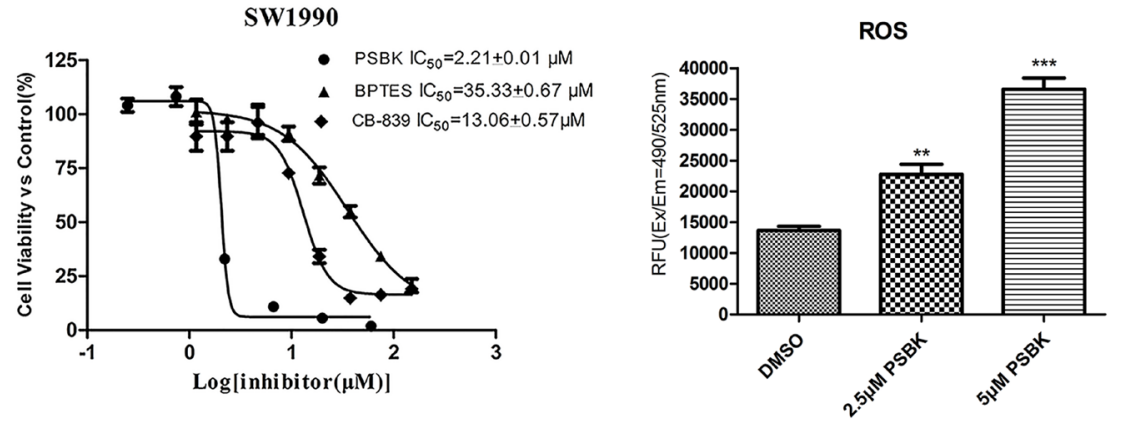

$\mathrm{D}$
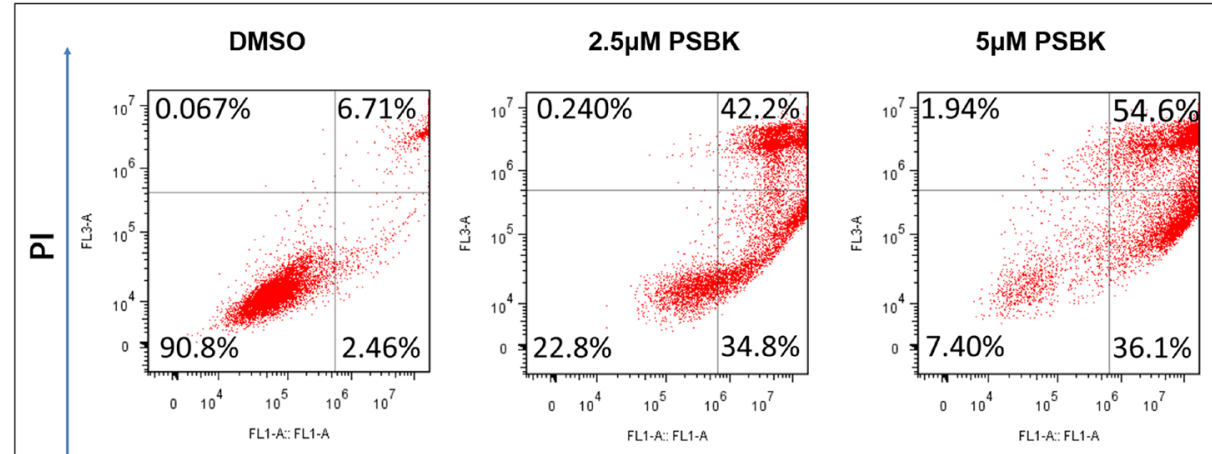

\section{Annexin V}

$\mathrm{E}$

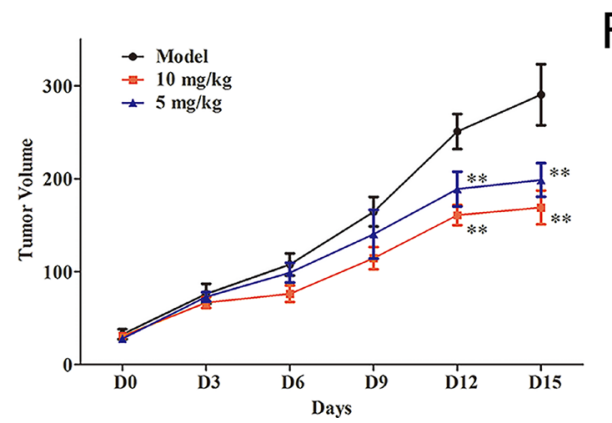

F

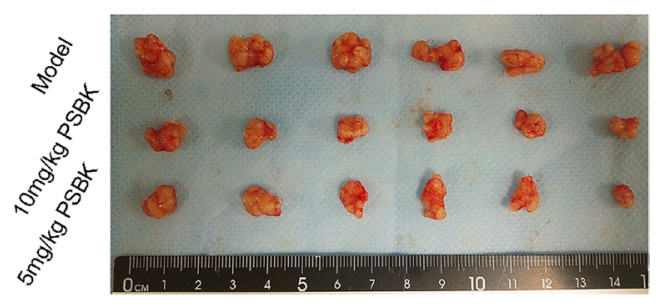

Figure 6: Physapubescin K (PSBK) inhibits SW1990 cell proliferation both in vitro and in vivo. (A) DAPI and EdU double staining was used to determine the effect of different concentrations of physapubescin K on the proliferation of SW1990 cells. BPTES and CB-839 were used as positive control. (B) The $\mathrm{IC}_{50}$ of PSBK to SW1990 measured by CCK8 method was $2.21 \pm 0.01 \mu \mathrm{M}$. (C) SW1990 cell treated with $2.5 \mu \mathrm{M}$ or $5 \mu \mathrm{M}$ PSBK in $0.1 \%$ DMSO or with $0.1 \%$ DMSO (control) for $24 \mathrm{~h}$, The ROS level were measured by fluorescence detection in Ex/Em 490/525 nm. (D). Cell apoptotic death analyzed by Annexin V/PI staining. (E) The average tumor volumes of vehicletreated control mice $(n=6)$ and PSBK treated mice $(n=6,5$ or $10 \mathrm{mg} / \mathrm{kg}$ per day via intraperitoneal injection) were plotted over 15 days after tumor cell injection. (E) After 2-week treatment, differences in tumor size are shown. The asterisk ${ }^{* *}$ indicates a significant increased tumor size $(P<0.01)$ in the vehicle-treated group compared with the PSBK-treated group as determined by one-way analysis of variance. 
Table 3: $\mathrm{IC}_{50}$ values $a$ of physapubescin $\mathrm{K}$ against human cancer cell lines

\begin{tabular}{lcccc}
\hline \multirow{2}{*}{ No. } & \multicolumn{4}{c}{ Human cancer cell lines $^{\mathrm{a}}$} \\
\cline { 2 - 5 } & LO2 & SW1990 & HCC827-ER & HT1080 \\
\hline physapubescin K & $11.7 \pm 0.32$ & $2.21 \pm 0.01$ & $0.72 \pm 0.22$ & $2.85 \pm 0.60$ \\
\hline
\end{tabular}

${ }^{a}$ Results are expressed as $\mathrm{IC}_{50}$ values in $\mu \mathrm{M}$.

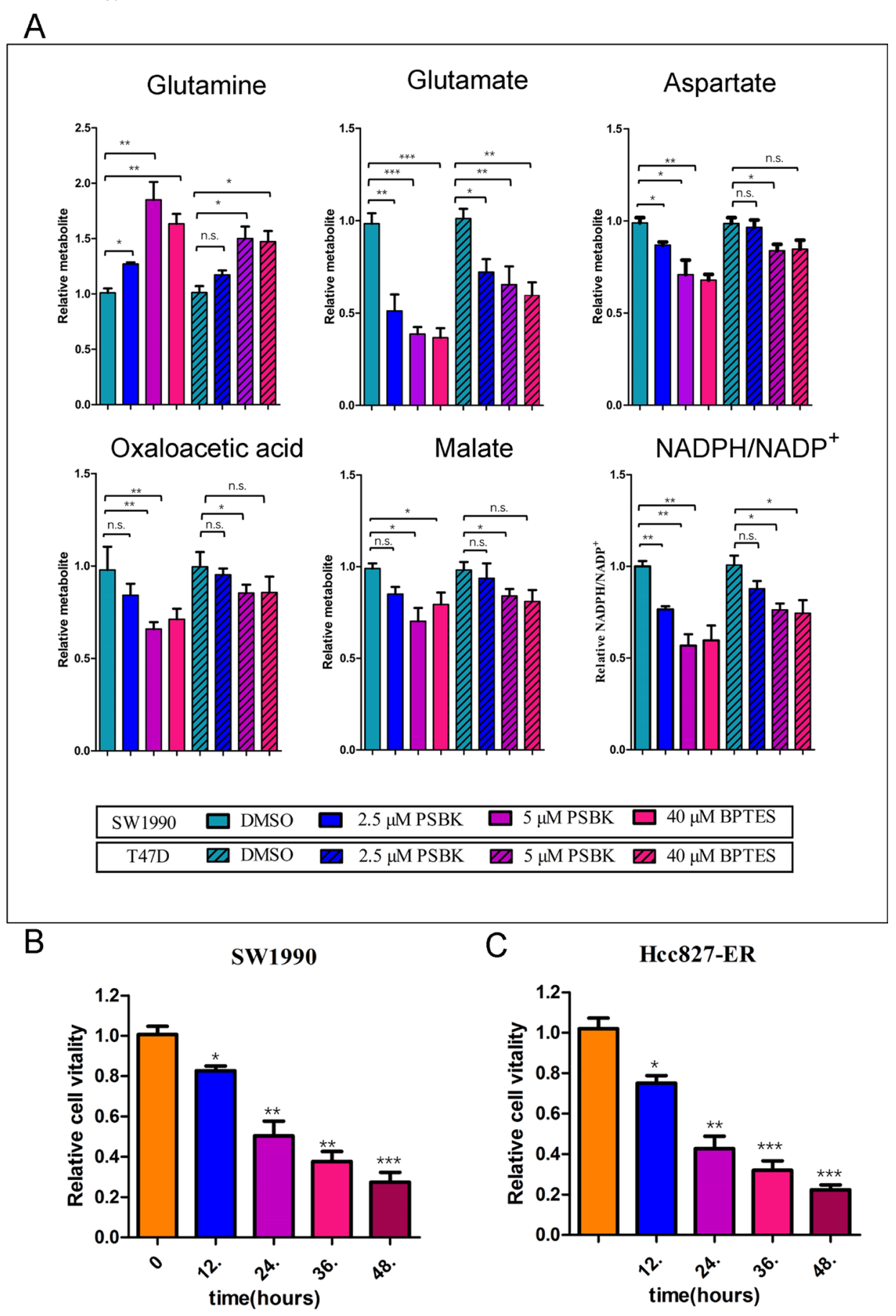

Figure 7: Physapubescin K (PSBK) could block glutamine metabolism. (A) Relative intracellular metabolite levels and $\mathrm{NADPH} / \mathrm{NADP}^{+}$were measured in SW1990 cells or T47D treated with DMSO, 2.5 or $5 \mu \mathrm{M}$ PSBK for 4 hours. BPTES was used as a positive control. Comparisons of treated and untreated conditions were performed by unpaired $t$-test: ${ }^{*} P<0.05$; ${ }^{* *} P<0.01 ;{ }^{* * *} P<0.001$; ns means no significant difference. (B) After SW1990 cells treated with $2 \mu \mathrm{M}$ PSBK in $0.06 \%$ DMSO or with $0.06 \%$ DMSO (control), viable cells were measured by CCK 8 on 12, 24, 36 and $48 \mathrm{~h}$. (C) After HCC 827-ER cells treated with $0.5 \mu \mathrm{M}$ PSBK in $0.015 \%$ DMSO or with $0.015 \%$ DMSO (control), viable cells were measured by CCK 8 on 12, 24, 36 and $48 \mathrm{~h}$. 
that validated the results of virtual screening. MST assays quantitatively measured the affinity between physapubescin $\mathrm{K}$ and recombinant KGA protein, and cellular thermal shift assay (CETSA) further confirmed its strong affinity with the intracellular KGA. CCK8 assay displayed that physapubescin $\mathrm{K}$ could selectively inhibit glutamine dependent cancer cell proliferation with dose and time dependent manner. According to previous studies, blocking glutamine metabolism can induce apoptosis under oxidative stress. Analogues of physapubescins $\mathrm{K}$, like physapubescins and physapubescins $\mathrm{B}[32,33]$, have been reported to possess the effect of promoting
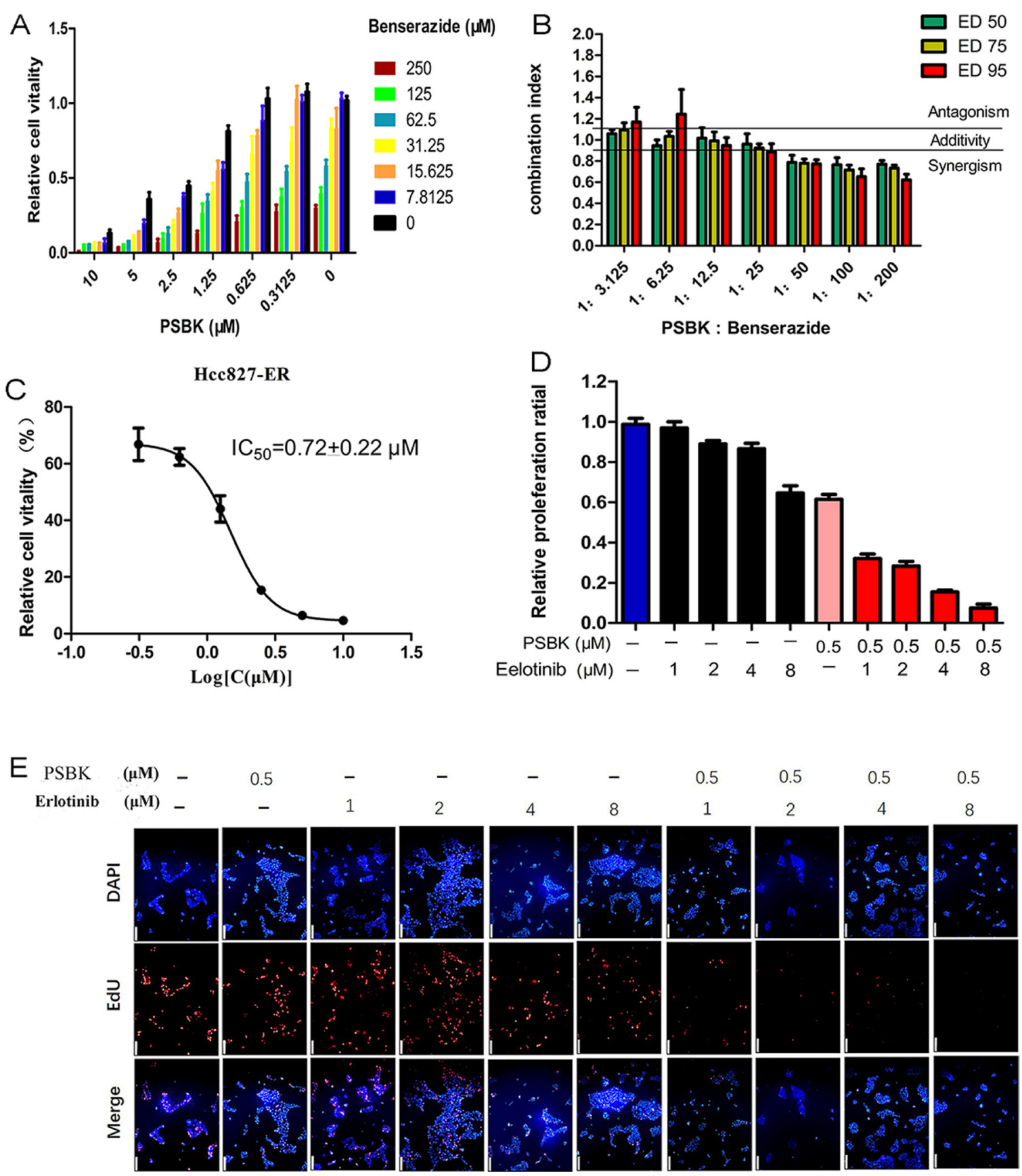

Figure 8: Synergy of physapubescin K (PSBK) in combination treatments. (A) Cells were cultured for 1 day with or without the indicated doses of PSBK and benserazide, and cell viability was evaluated by CCK8 assay. (B) At the indicated concentration ratio of PSBK: benserazide combinations at different effect levels, $\mathrm{ED}_{50}, \mathrm{ED}_{75}$ and $\mathrm{ED}_{95}$ were calculated using the CompuSyn software. Bars represent the mean $\pm \mathrm{SD}$ of two different experiments performed in triplicates. Dashed horizontal lines indicate antagonism (CI $>1.1)$, additivity $(0.9<\mathrm{CI}<1.1)$ and synergy $(\mathrm{CI}<0.9)$. (C) The $\mathrm{IC}_{50}$ of PSBK to HCC827-ER measured by CCK8 method was $0.72 \pm 0.22 \mu \mathrm{M}$. (D, E) DAPI and EdU double staining was used to determine the effect of indicated doses of PSBK and erlotinib on the proliferation of SW1990 cells (E). The proportion of cells in proliferation is counted by manual counting (D). 
cell apoptosis. Similarly, our study demonstrated that physapubescins $\mathrm{K}$ could also induce apoptosis with significantly increased ROS levels. Combined with our previous study [19], the $4 \beta$-hydroxy-2-en-1-one group in ring $\mathrm{A}$ and $5 \beta, 6 \beta$-epoxy group in ring $\mathrm{B}$, were essential for their antitumor effects, which was in agreement with previous reports on structure-activity relationship [21, 34].

It is worthy of mentioning that physapubescin $\mathrm{K}$ showed anti-proliferative activity in a PDCA cell line SW1990 both in vitro and in vivo. It blocked SW1990 cells in glutamine consumption by increasing intracellular level of glutamine and decreasing glutamate and its downstream metabolites. Further assay demonstrated that this inhibition of cell proliferation could be reversed by the addition of glutamate.

A combination of therapies to treat malignancies was at the forefront of research with the aim to reduce drug dosage and side effects, as well as diminish the possibility of resistance emergence. Aerobic glycolysis was an important cancer metabolism pathway, in which hexokinase 2 (HK2) was a crucial enzyme controlling the first step of glycolysis. Benserazide was identified as a novel HK2 inhibitor in our previous study [27]. In this investigation, physapubescin $\mathrm{K}$ showed synergistic inhibitory effects in combination with benserazide on SW1990 cells, suggesting that targeting at both glucose and glutamine metabolism pathways could produce improved efficacy and cytotoxicity with smaller dose of both compounds. More detailed synergistic mechanisms of physapubescin $\mathrm{K}$ and benserazide still need to be further investigated.

Interestingly, physapubescin $\mathrm{K}$ exhibited potent inhibitory effects on the erlotinib-resistant human nonsmall cell lung cancer cell line HCC827-ER with an $\mathrm{IC}_{50}$ of nanomolar grade. What is more, physapubescin $\mathrm{K}$ could reverse the resistance of HCC827-ER cells to erlotinib, showing a synergistic effect. In this regard, physapubescin $\mathrm{K}$ may be further developed as a potent sensitizer for HCC827-ER cells to erlotinib, which could be used in combination with erlotinib for the treatment of erlotinib-resistant non-small cell lung cancer. All these tend to imply that physapubescin $\mathrm{K}$ is at least a good lead compound for designing novel KGA inhibitors. As far as we know, physapubescin $\mathrm{K}$, a new withanolide-type compound is the first kind of natural KGA inhibitor, which was found in our ongoing phytochemical investigations on $P$. pubescens L. In our future study, more pre-clinical evaluations will be further carried out.

\section{MATERIALS AND METHODS}

\section{Extraction and isolation}

The dried stem and leaves of $P$. pubescens L. (50 Kg) collected from Shenyang, Liaoning Province, China, were cut into small pieces and extracted with $75 \%$ ethanol $(500 \mathrm{~L} \times 2)$. The resulting extract $(6.5 \mathrm{~kg})$ was concentrated in vacuo, suspended in $\mathrm{H}_{2} \mathrm{O}(12 \mathrm{~L})$, and partitioned successively with petroleum ether $(12 \mathrm{~L} \times 3)$, EtOAc $(12 \mathrm{~L} \times 3)$, and $n$ - $\mathrm{BuOH}(12 \mathrm{~L} \times 3)$ to give three fractions. The EtOAc fraction (537 g) was subjected to a silica gel $\mathrm{CC}(14 \times 100 \mathrm{~cm})$ that was eluted with $\mathrm{CH}_{2} \mathrm{Cl}_{2} /$ $\mathrm{CH}_{3} \mathrm{OH}(100: 1,40: 1,20: 1,10: 1,4: 1,2: 1,1: 1$ and $0: 1 \mathrm{v} / \mathrm{v})$ to obtain nine combined subfractions (E1-E9). Fraction E3 (38 g) was subjected to a silica gel column $(8 \times 50$ $\mathrm{cm}$ ) and eluted with $\mathrm{CH}_{2} \mathrm{Cl}_{2}$ /acetone (from 100:1 to 1:1, $\mathrm{v} / \mathrm{v})$ to produce eight subfractions (E31-E38). E36 (7.8 g) was chromatographed repeatedly on a Sephadex LH-20 column $(3.0 \times 80 \mathrm{~cm})$ that was eluted with $\mathrm{CH}_{2} \mathrm{Cl}_{2} / \mathrm{CH}_{3} \mathrm{OH}$ $(1: 1, \mathrm{v} / \mathrm{v})$ and further purified via preparative HPLC $(60 \%$ $\left.\mathrm{CH}_{3} \mathrm{OH} / \mathrm{H}_{2} \mathrm{O}\right)$ to yield physapubescin $\mathrm{K}(750 \mathrm{mg})$.

\section{Molecular docking}

Crystal structure of human KGA (PDB code: 3VP1) was obtained from the Protein Data Bank. The docking was operated by ICM 3.8.2 modeling software on an Intel i7 4960 processor (MolSoft LLC, San Diego, CA). And ligand binding pocket residues were selected by graphical tools in ICM software to create the boundaries of docking search. The glucose was the co-crystallized ligand in this crystal structure for docking, and it was deleted when setting up the receptor. In docking calculation, potential energy maps of the receptor were calculated using default parameters. Compounds were inputted into ICM and an index file was created. Conformational sampling was based on the Monte Carlo procedure 30, and finally the lowest-energy and the most favorable orientation of the ligand was selected $[23,35]$.

\section{Cloning, expression and purification of KGA}

Specific details were referenced to our previous work [19]. Briefly, The catalytical domain of human KGA (cKGA) encoding amino acids 221-553 was cloned into $\mathrm{pET} 26 \mathrm{~b}$ vector with $\mathrm{C}$-terminal His tag. The cKGA was then expressed in E.coli BL21 (DE3)-RIL-Condon plus. Cultures were grown in LB media contain 35 $\mathrm{mg} / \mathrm{L}$ kanamycin at $37^{\circ} \mathrm{C}$ to $\mathrm{OD}$ value in $0.6-0.8$, then induced at $16^{\circ} \mathrm{C}$ with $0.4 \mathrm{mM}$ IPTG for $16 \mathrm{~h}$. Cultures were harvested by centrifugation at $3500 \mathrm{~g}$ for 8 minutes. Cell pellets were sonicated in a buffer [6] containing $50 \mathrm{mM}$ Hepes (pH 7.5), $500 \mathrm{mM} \mathrm{NaCl}, 5 \mathrm{mM}$ imidazole, 10 glycerol, $1 \mathrm{mM}$ DTT, $0.1 \%$ Triton X-100, and final $1 \mathrm{mM}$ PMSF (Sigma-Aldrich USA). The cKGA were purified by affinity chromatography by Ni-NTA agarose, and further purified by size exclusion chromatography (Superdex 200, GE-health care, USA). The purified cKGA was stored in buffer containing $20 \mathrm{mM}$ Hepes ( $\mathrm{pH} 7.5$ ), $200 \mathrm{mM} \mathrm{NaCl}, 10 \%$ glycerol and $3 \mathrm{mM}$ DTT. 


\section{In vitro $\mathrm{IC}_{50}$ assays for $\mathrm{KGA}$ inhibition}

The KGA profiling assays were to evaluate the compound-dependent inhibition of KGA in vitro catalytic assay [17]. Specific details were referenced to our previous work [19]. Briefly, the KGA catalyzed the glutamine into glutamate plus ammonium, and then glutamate plus NAD converted to $\alpha$-ketoglutarate and NADH by the catalysis of GDH. The elevated absorbance at $340 \mathrm{~nm}$ with the form of NADH was recorded using a microplate reader. The enzymatic activity was measured in $100 \mu \mathrm{L}$ system. Mixed buffer containing $0.15 \mathrm{M} \mathrm{K}_{2} \mathrm{HPO}_{4}, 50 \mathrm{mM}$ Tris-Acetate $\mathrm{pH} 8.6,0.1 \mathrm{mg} / \mathrm{mL}$ bovine serum albumin (BSA), $0.25 \mathrm{mM}$ EDTA, $1 \mathrm{mM}$ DTT, $4 \mathrm{mM}$ NAD were prepared. Then, $10 \mathrm{mM}$ glutamine, 1 unit of glutamate dehydrogenase (GDH) and inhibitor were added in the mix. Final concentration of $1 \mu \mathrm{M} \mathrm{cKGA}$ was added to initiate the reaction. Generation of NADH was monitored by $340 \mathrm{~nm}$ absorbance every minute for 20 minutes at $37^{\circ} \mathrm{C}$. The $\mathrm{IC}_{50}$ values were calculated by fitted regression equation using the-log plot (GraphPad Prism). Each value was on behalf of the means $\pm \mathrm{SD}$ of three independent tests, each with three replicates.

\section{Microscale thermophoresis (MST) Assay}

The ability of the compound to bind with purified KGA was analyzed with MST. Specific details were referenced to our previous work [19]. Briefly, The protein was labeled with the Monolith NT ${ }^{\mathrm{TM}}$ Protein Labeling Kit RED (Cat\#L001) according to the manufacturer's instructions. Labeled KGA were diluted in a $20 \mathrm{mM}$ HEPES (pH 7.5) and 0.05 (v/v)\% Tween-20 at $200 \mathrm{nM}$. Compounds were diluted in a range of concentration steps and incubated with KGA for $10 \mathrm{~min}$ at room temperature. Samples were loaded into Monolith TM standard-treated capillaries and the thermophoresis was carried out at $26^{\circ} \mathrm{C}$ after 10 min incubation on a Monolith NT.115 instrument (Nano Temper Technologies, München, Germany). Data were obtained with $100 \%$ LED power and 20\% MST. $\mathrm{Kd}$ values were fitted by using the NT Analysis software (Nano Temper Technologies, München, Germany).

\section{Cellular thermal shift assay (CETSA)}

The ability of compounds to interact with, and thereby stabilize the target in intact cells, was analyzed essentially as described by Alshareef A et al. [36]. Briefly, cells cultured in $10-\mathrm{cm}$ tissue culture dishes at about $90 \%$ confluence were treated with media containing DMSO or $10 \mu \mathrm{M}$ physapubescin $\mathrm{K}$ for 4 hours. After treatment, cells were detached with cell scraper, collected by centrifugation and subsequently resuspended in PBS. The cell suspension was aliquoted into seven PCR tubes and heated for 3 minutes to $40,42,44,46,48,50$ or $52^{\circ} \mathrm{C}$.
Subsequently, cells were lysed using liquid nitrogen and two repeated cycles of freeze-thaw. Precipitated proteins were removed by centrifugation at $13,000 \mathrm{~g}$ for 20 minutes. Soluble proteins, collected in the supernatant, for further Western blot analysis.

\section{Cytotoxicity assay}

The HCC827-ER cell line was kindly provided by Professor Jianbin Wang (Institute of Translational Medicine, Nanchang University, China). The SW1990, HT1080, and A375-S2 human tumor cell lines were obtained from ATCC (Manassas, VA, USA). HCC827-ER cells were cultured in RPMI-1640 medium with $10 \%$ fetal bovine serum (FBS). SW1990, HT1080, and LO2 cells were cultured in DMEM medium with $10 \%$ fetal bovine serum (FBS). All of these cells were cultured at $37^{\circ} \mathrm{C}$ in a humidified atmosphere with $5 \% \mathrm{CO}_{2}$. To estimate cell viability, cells (5000/well) were separately seeded in 96well plates for $24 \mathrm{~h}$ at $37^{\circ} \mathrm{C}$ in a $5 \% \mathrm{CO}_{2}$ incubator. The attached cells were fed with fresh medium containing various concentrations of physapubescin $\mathrm{K}(0-100 \mu \mathrm{M})$ for additional $48 \mathrm{~h}$, using BPTES as the positive control. After culturing for various times, the cytotoxicity of physapubescin $\mathrm{K}$ was measured using a CCK8 assay kit according to the manufacturer's instructions. All the experiments were performed in triplicate, and the mean absorbance values were calculated. The $\mathrm{IC}_{50}$ values of the compounds were derived from the mean OD values of the triplicate tests versus the drug concentration curves.

\section{EdU and DAPI double staining to detect cell proliferation}

The logarithmic growth phase cells were seeded in 24-well plates at $2 \times 10^{4} \sim 5 \times 10^{5}$ cells per well. After 4-6 h, the medium was removed, the medium containing no or different concentrations of compound was replaced, and $50 \mu \mathrm{M}$ of EdU was added. $2 \mathrm{~h}$ later, the medium was removed, cells washed by PBS. $200 \mu \mathrm{L}$ of cell fixative (i.e., PBS containing $4 \%$ paraformaldehyde) was added and incubated at room temperature for 30 minutes. The solution was discarded and $200 \mu \mathrm{L}$ of $2 \mathrm{mg} / \mathrm{mL}$ glycine was added to each well. After 5 minutes of incubation, the glycine solution was discarded. Each well washed with $200 \mu \mathrm{L}$ of PBS, rinse for 5 minutes, and PBS was removed. Apollo staining was added to each well with $200 \mu \mathrm{L}$ of 1 X Apollo ${ }^{\circledR}$ staining solution. After incubation for 30 minutes at room temperature and decolorization, the reaction solution was discarded. Similarly, $200 \mu \mathrm{L}$ of $1 \times$ Hoechst 33342 solution was added to each well to dye the total DNA. After 30 minutes of incubation at room temperature and the reaction solution was discarded, and then the images were captured and analyzed by fluorescence microscopy. 


\section{Cell proliferation assay}

SW1990, HCC827-ER, T47D and LO2 cells were seeded at a density of $2 \times 10^{3}$ per well into 96 -well plates. Cell proliferation was assessed by incubating them with Cell Counting Kit-8 reagents (Dojindo, Shanghai, China) for $24 \mathrm{~h}, 48 \mathrm{~h}, 72 \mathrm{~h}, 96 \mathrm{~h}$ at $37^{\circ} \mathrm{C}$ and measuring the absorbance at $450 \mathrm{~nm}$. The experiment was performed in triplicate.

\section{Western blot analysis}

The harvested cells were lysed using liquid nitrogen and two repeated cycles of freeze-thaw. Insoluble debris was removed by centrifugation and the concentration of total proteins was determined using BCA Protein Assay Kit (Beyotime, China). Then lysate protein $(20-40 \mu \mathrm{g})$ was subjected to $10 \%$ SDS-PAGE and electrophoretically transferred to polyvinylidene difluoride membranes (PVDF) (Millipore, USA). The membranes were sequentially blocked with $5 \%$ non-fat milk and incubated overnight with the following primary antibodies: $\beta$-actin (A2228), KGA (20170-1-AP). Protein bands were visualized using an enhanced chemiluminescence reagent (ECL Plus) (GE Healthcare, USA) after hybridization with a HRP conjugated secondary antibody. All experiments were performed in triplicate and analyzed by Quantity One software.

\section{Measurement of intracellular metabolism level}

$\mathrm{NADPH} / \mathrm{NADP}^{+}$ratio was determined by using $\mathrm{NADP}^{+} / \mathrm{NADPH}$ Quantification Colorimetric Kit (BioVision, \#K347-100). The abundance of intracellular glutamine (KeyGen, Nanjing, China A124), glutamate (KeyGen, Nanjing, China A074), (BioVision, \#K778), aspartate (BioVision, \#K552), oxaloacetate (BioVision, \#K659) and malate (BioVision, \#K637) was determined by using quantification kits, according the manufacturer's instruction. Briefly, $5 \times 10^{6}$ cells (10-cm dishes) were collected during log-phase growth by cell scraper, homogenized in $0.2 \mathrm{~mL}$ of provided buffers (on ice), and centrifuged at $4^{\circ} \mathrm{C}$ for $10 \mathrm{~min}$ at $13,000 \mathrm{~g}$. Supernatants were deproteinized using $10 \mathrm{~K}$ Ultrafiltration tube (Millipore, USA), analyzed and compared to standard curves. The signals obtained were normalized to the protein concentration calculated upon processing a parallel 10-cm dish.

\section{ROS Quantification}

DCFDA assay was performed $24 \mathrm{~h}$ after interfered with difference concentration of physapubescin $\mathrm{K}$ or DMSO. Cells were incubated with $5 \mu \mathrm{M} 2^{\prime}, 7^{\prime}$-dichlorod ihydrofluorescein diacetate (DCFDA, KeyGen, Nanjing, China A124) for $30 \mathrm{~min}$. Cells were washed twice with PBS to remove excess DCFDA, and the labeled cells were then collected in PBS. The fluorescent of $2^{\prime}, 7^{\prime}$-dichlorofluorescein (DCF) was proportionate to ROS generation and was measured by microplate reader.

\section{Flow cytometric analysis for apoptosis}

SW1990 cells were cultured in six-well plates and treated with different concentrations of physapubescin $\mathrm{K}$ for $24 \mathrm{~h}$. Then the cells were harvested, washed twice with ice-cold PBS, and mixed in $100 \mu \mathrm{L}$ of $1 \times$ binding buffer (10 mM HEPES/ NaOH, pH 7.4, $140 \mathrm{mM} \mathrm{NaCl}, 2.5 \mathrm{mM}$ $\mathrm{CaCl}_{2}$ ). After incubating with Annexin-V and PI staining liquid (Nanjing KeyGen Biotech. Inc.) for $15 \mathrm{~min}$ at room temperature, the cells were examined by flow cytometry (BD Biosciences, FACSCalibur).

\section{Antitumor efficacy of physapubescin $K$ in xenograft mouse model in vivo}

All animal experiments were performed in accordance with the Guide for the Care and Use of Laboratory Animals of Tongji Medical College, Huazhong University of Science and Technology and approved by the Ethics Committee. CB-17/ SCID mice (male, 4 weeks old) were purchased from Beijing HFK Bioscience CO., LTD (Beijing, China). SW1990 cells were inoculated subcutaneously $\left(3 \times 10^{6}\right.$ cells $)$ into the left flank of each mouse. Six days later, mice were randomly divided into six groups and were injected i.p. daily for 16 days with one of the following treatments: (1) natural saline group $(n=10)$; (2) $5 \mathrm{mg} / \mathrm{Kg}$ physapubescin $\mathrm{K}(n=10)$; (3) 10 $\mathrm{mg} / \mathrm{Kg}$ physapubescin $\mathrm{K}(n=10)$. The dose volume was $0.1 \mathrm{~mL} / 10 \mathrm{~g}$ body weight, and the weights of mice were recorded every day. Meanwhile, the tumor volumes were measured with vernier calipers and calculated by the following formula: $(\mathrm{A} \times \mathrm{B} 2) / 2$, where $\mathrm{A}$ was length and $\mathrm{B}$ was width of the two-dimension tumor. After animals were sacrificed, tumor weights were measured. The inhibition ratio (\%) was calculated using the following equation: $\mathrm{I} \%$ $=100 \% \times\left[\mathrm{W}_{\text {tumor (vehicle) }}-\mathrm{W}_{\text {tumor (treated) }}\right] / \mathrm{W}_{\text {tumor (vehicle) }}$

\section{Statistical analysis}

Statistical analysis of the data was performed using Graph Pad Prism 5.0 software. The data were expressed as the means $\pm \mathrm{SD}$. Values were analyzed using SPSS version 12.0 software by one-way analysis of variance (ANOVA), and $p<0.05$ was considered statistically significant.

\section{Abbreviations}

KGA: Kidney-type glutaminase; PSBK: physapubescin K; PDAC: pancreatic ductal adenocarcinoma; MST: Microscale thermophoresis; CETSA The cellular thermal shift assay; CCK-8: Cell Counting Kit8; PVDF: Polyvinylidene difluoride membranes. 


\section{Author contributions}

HL and LXC designed the study, provided material supports and polished the manuscript. CRW, performed experiments, analyzed the data and drafted the manuscript. MZZ, SYG, SSL, LC, YKY, LQW and JCL carried out parts of the experiments. All authors read and approved the final manuscript.

\section{ACKNOWLEDGMENTS}

We acknowledge support from National Natural Science Foundation of China (NSFC) (grant number 81773594, 3127039), the Fundamental Research Fund for the Central Universities (grant number 2017KFYXJJ151), Liaoning Province Natural Science Foundation (grant number 201602689), Scientific Research Foundation for the Returned Overseas Chinese Scholars of Shenyang Pharmaceutical University (grant number GGJJ2015103), and 2015 Career Development Program for Young and Middle-aged Teachers of Shenyang Pharmaceutical University (grant number ZQN2015015).

\section{CONFLICTS OF INTEREST} interests.

The authors declare that they have no competing

\section{FUNDING}

This work was supported by the National Natural Science Foundation of China (NSFC) (grant number 81773594, 3127039), the Fundamental Research Fund for the Central Universities (grant number 2017KFYXJJ151), Liaoning Province Natural Science Foundation (grant number 201602689), Scientific Research Foundation for the Returned Overseas Chinese Scholars of Shenyang Pharmaceutical University (grant number GGJJ2015103), and 2015 Career Development Program for Young and Middle-aged Teachers of Shenyang Pharmaceutical University (grant number ZQN2015015).

\section{REFERENCES}

1. Warburg O. On the origin of cancer cells. Science. 1956; 123:309-314.

2. DeBerardinis RJ, Cheng TQ. Q's next: the diverse functions of glutamine in metabolism, cell biology and cancer. Oncogene. 2010; 29:313-324. https://doi.org/10.1038/ onc.2009.358.

3. Hensley CT, Wasti AT, DeBerardinis RJ. Glutamine and cancer: cell biology, physiology, and clinical opportunities. J Clin Invest. 2013; 123:3678-3684. https://doi. org/10.1172/JCI69600.
4. Erickson JW, Cerione RA. Glutaminase: A Hot Spot For Regulation Of Cancer Cell Metabolism? Oncotarget. 2010; 1:734-740. https://doi.org/10.18632/oncotarget.208.

5. Wise DR, Thompson CB. Glutamine addiction: a new therapeutic target in cancer. Trends Biochem Sci. 2010; 35:427-433. https://doi.org/10.1016/j.tibs.2010.05.003.

6. Altman BJ, Stine ZE, Dang CV. From Krebs to clinic: glutamine metabolism to cancer therapy. Dang. Nat Rev Cancer. 2016; 16:619-634. https://doi.org/10.1038/ nrc.2016.71.

7. Thangavelu K, Pan CQ, Karlberg T, Balaji G, Uttamchandani M, Suresh V, Schuler H, Low BC, Sivaraman J. Structural basis for the allosteric inhibitory mechanism of human kidney-type glutaminase (KGA) and its regulation by Raf-Mek-Erk signaling in cancer cell metabolism. Proc Natl Acad Sci U S A. 2012; 109:7705-7710. https://doi.org/10.1073/pnas.1116573109.

8. Cohen R, Neuzillet C, Tijeras-Raballand A, Faivre S, de Gramont A, Raymond E. Targeting cancer cell metabolism in pancreatic adenocarcinoma. Oncotarget. 2015; 6:16832-47. https://doi.org/10.18632/oncotarget.4160.

9. Wise DR, DeBerardinis RJ, Mancuso A, Sayed N, Zhang XY, Pfeiffer HK, Nissim I, Daikhin E, Yudkoff M, McMahon SB, Thompson CB. Myc regulates a transcriptional program that stimulates mitochondrial glutaminolysis and leads to glutamine addiction. Proc Natl Acad Sci U S A. 2008; 105:18782-18787. https://doi.org/10.1073/pnas.0810199105.

10. Gao P, Tchernyshyov I, Chang TC, Lee YS, Kita K, Ochi T, Zeller KI, De Marzo AM, Van Eyk JE, Mendell JT, Dang CV. c-Myc suppression of miR-23a/b enhances mitochondrial glutaminase expression and glutamine metabolism. Nature. 2009; 458:762-765. https://doi. org/10.1038/nature07823.

11. Xu X, Li J, Sun X, Guo Y, Chu D, Wei L, Li X, Yang G, Liu X, Yao L, Zhang J, Shen L. Tumor suppressor NDRG2 inhibits glycolysis and glutaminolysis in colorectal cancer cells by repressing c-Myc expression. Oncotarget. 2015; 6:26161-76. https://doi.org/10.18632/oncotarget.4544.

12. Wang JB, Erickson JW, Fuji R, Ramachandran S, Gao P, Dinavahi R, Wilson KF, Ambrosio AL, Dias SM, Dang CV, Cerione RA. Targeting mitochondrial glutaminase activity inhibits oncogenic transformation Cancer Cell. 2010; 18:207-219. https://doi.org/10.1016/j.ccr.2010.08.009.

13. Lora J, Alonso FJ, Segura JA, Lobo C, Marquez J, Mates JM. Antisense glutaminase inhibition decreases glutathione antioxidant capacity and increases apoptosis in Ehrlich ascitic tumour cells. Eur J Biochem. 2004; 271:4298-4306. https://doi.org/10.1111/j.1432-1033.2004.04370.x.

14. Ramachandran S, Pan CQ, Zimmermann SC, Duvall B, Tsukamoto T, Low BC, Sivaraman J. Structural basis for exploring the allosteric inhibition of human kidney type glutaminase. Oncotarget. 2016; 7:57943-57954. https://doi. org/10.18632/oncotarget.10791. 
15. Thangavelu K, Chong QY, Low BC, Sivaraman J. Structural basis for the active site inhibition mechanism of human kidney-type glutaminase (KGA). Sci Rep. 2014; 4:38273833. https://doi.org/10.1038/srep03827.

16. Jacque N, Ronchetti AM, Larrue C, Meunier G, Birsen R, Willems L, Saland E, Decroocq J, Maciel TT, Lambert M, Poulain L, Hospital MA, Sujobert P, et al. Targeting glutaminolysis has antileukemic activity in acute myeloid leukemia and synergizes with BCL-2 inhibition. Blood. 2015; 126:1346-1356. https://doi.org/10.1182/blood-2015-01-621870.

17. Gross MI, Demo SD, Dennison JB, Chen L, ChernovRogan T, Goyal B, Janes JR, Laidig GJ, Lewis ER, Li J, Mackinnon AL, Parlati F, Rodriguez ML, et al. Antitumor activity of the glutaminase inhibitor CB-839 in triple-negative breast cancer. Mol Cancer Ther. 2014; 13:890-901. https://doi.org/10.1158/1535-7163.

18. Newman DJ, Cragg GM. Natural Products as Sources of New Drugs from 1981 to 2014. J Nat Prod. 2016; 79:629-661. https://doi.org/10.1021/acs.jnatprod.5b01055.

19. Cheng L, Wu CR, Zhu LH, Li H, Chen LX. Physapubescin, a natural withanolide as a kidney-type glutaminase (KGA) inhibitor. Bioorg Med Chem Lett. 2017; 27:1243-1246. https://doi.org/10.1016/j.bmcl.2017.01.057.

20. Kirson I, Gottlieb HE, Glotter E. Physapubescin, a new ergostane-type steroid from Physalis pubescens L. J Chem Res Synop. 1980; 125:2134-215. https://doi.org/10.1039/ p19800002700.

21. Xia G, Li Y, Sun J, Wang L, Tang X, Lin B, Kang N, Huang J, Chen L, Qiu F. Withanolides from the stems and leaves of Physalis pubescensand their cytotoxic activity. Steroids. 2016; 115:136-146. https://doi.org/10.1016/j. steroids.2016.09.002.

22. Chao CH, Chou KJ, Wen ZH, Wang GH, Wu YC, Dai CF, Sheu JH. Paraminabeolides A-F, cytotoxic and antiinflammatory marine withanolides from the soft coral Paraminabea acronocephala. J Nat Prod. 2011, 74:1132-41. https://doi.org/10.1021/np2000705.

23. Abagyan R, Totrov M, Kuznetsov D. ICM-A new method for protein modelling and design: Application to docking and structure prediction from the distorted native conformation. J Comput Chem. 1994; 15:488-506. https:// doi.org/10.1002/jcc.540150503.

24. Khavrutskii L, Yeh J, Timofeeva O, Tarasov SG, Pritt S, Stefanisko K, Tarasova N. Protein Rensing-fri metode for Binding Affinity Fastsettelse av mikroskala Thermophoresis. JoVE. 2013; 50541-50546. https://doi. org/10.3791/50541.

25. Martinez Molina D, Jafari R, Ignatushchenko M, Seki T, Larsson EA, Dan C, Sreekumar L, Cao Y, Nordlund P. Monitoring drug target engagement in cells and tissues using the cellular thermal shift assay. Science. 2013; 341:84-87. https://doi.org/10.1126/science.1233606.
26. Elgogary A, Xu Q, Poore B, Alt J, Zimmermann SC, Zhao L, Fu J, Chen B, Xia S, Liu Y, Neisser M, Nguyen C, Lee R, et al. Combination therapy with BPTES nanoparticles and metformin targets the metabolic heterogeneity of pancreatic cancer. Proc Natl Acad Sci U S A. 2016; 113:E5328-5336. https://doi.org/10.1073/pnas.1611406113.

27. Li W, Zheng M, Wu S, Gao S, Yang M, Li Z, Min Q, Sun W, Chen L, Xiang G, Li H. Benserazide, a dopadecarboxylase inhibitor, suppresses tumor growth by targeting hexokinase 2. J Exp Clin Cancer Res. 2017; 36:58. https://doi. org/10.1186/s13046-017-0530-4.

28. Xie C, Jin J, Bao X, Zhan WH, Han TY, Gan M, Zhang C, Wang J. Inhibition of mitochondrial glutaminase activity reverses acquired erlotinib resistance in non-small cell lung cancer. Oncotarget. 2016; 7:610-621. https://doi. org/10.18632/oncotarget.6311.

29. Li R, Hu Z, Sun SY, Chen ZG, Owonikoko TK, Sica GL, Ramalingam SS, Curran WJ, Khuri FR, Deng X. Niclosamide overcomes acquired resistance to erlotinib through suppression of STAT3 in non-small cell lung cancer. Mol Cancer Ther. 2013; 12:2200-2212. https://doi. org/10.1158/1535-7163.

30. Han T, Guo M, Zhang T, Gan M, Xie C, Wang JB. A novel glutaminase inhibitor-968 inhibits the migration and proliferation of non-small cell lung cancer cells by targeting EGFR/ERK signaling pathway. Oncotarget. 2017; 8:28063-28073. https://doi.org/10.18632/oncotarget.14188.

31. Ward PS, Thompson CB. Metabolic reprogramming: a cancer hallmark even warburg did not anticipate. Cancer Cell. 2012; 21:297-308. https://doi.org/10.1016/j.ccr.2012.02.014.

32. Chen L, Xia G, Qiu F, Wu C, Denmon AP, Zi X. Physapubescin selectively induces apoptosis in VHL-null renal cell carcinoma cells through down-regulation of HIF-2 $\alpha$ and inhibits tumor growth. Sci Rep. 2016; 6:32582. https://doi.org/10.1038/srep32582.

33. Xu J, Wu Y, Lu G, Xie S, Ma Z, Chen Z, Shen HM, Xia D. Importance of ROS-mediated autophagy in determining apoptotic cell death induced by physapubescin B. Redox Biol. 2017; 12:198-207. https://doi.org/10.1016/j. redox.2017.02.01.

34. Sun CP, Qiu CY, Yuan T, Nie XF, Sun HX, Zhang Q, Li HX, Ding LQ, Zhao F, Chen LX, Qiu F. Antiproliferative and Anti-inflammatory Withanolides from Physalis angulata, J Nat Prod. 2016; 79:1586-1597. https://doi.org/10.1021/acs. jnatprod.6b00094.

35. Li Z, Scheraga H. Monte Carlo-minimization approach to the multiple-minima problem in protein folding. Proc Natl Acad Sci U S A. 1987; 84:6611-6615.

36. Alshareef A, Zhang HF. The use of cellular thermal shift assay (CETSA) to study Crizotinib resistance in ALKexpressing human cancers. Sci Rep. 2016; 6:33710. https:// doi.org/10.1038/srep33710. 